\title{
The injury epidemiology of cyclists based on a road trauma registry
}

\author{
Emmanuelle Amoros ${ }^{1,2,3^{*}}$, Mireille Chiron ${ }^{1,2,3}$, Bertrand Thélot ${ }^{4}$ and Bernard Laumon ${ }^{1,2,3}$
}

\begin{abstract}
Background: Bicycle use has increased in some of France's major cities, mainly as a means of transport. Bicycle crashes need to be studied, preferably by type of cycling. Here we conduct a descriptive analysis.

Method: A road trauma registry has been in use in France since 1996, in a large county around Lyon (the Rhône, population 1.6 million). It covers outpatients, inpatients and fatalities. All injuries are coded using the Abbreviated Injury Scale (AIS). Proxies were used to identify three types of cycling: learning = children (0-10 years old); sports cycling = teenagers and adults injured outside towns; cycling as means of transport = teenagers and adults injured in towns. The study is based on 13,684 cyclist casualties (1996-2008).
\end{abstract}

Results: The percentage of cyclists injured in a collision with a motor vehicle was $8 \%$ among children, $17 \%$ among teenagers and adults injured outside towns, and 31\% among those injured in towns. The percentage of serious casualties (MAIS 3+) was 4.5\% among children, 10.9\% among adults injured outside towns and $7.2 \%$ among those injured in towns. Collisions with motor-vehicles lead to more internal injuries than bicycle-only crashes.

Conclusion: The description indicates that cyclist type is associated with different crash and injury patterns. In particular, cyclists injured in towns (where cycling is increasing) are generally less severely injured than those injured outside towns for both types of crash (bicycle-only crashes and collisions with a motor vehicle). This is probably due to lower speeds in towns, for both cyclists and motor vehicles.

\section{Background}

In some of France's major cities (Paris, Lyon, Lille,...) there has been an increase in cycling, mostly as a means of transport [1]. This is partly associated with local policies, such as the introduction of large self-service bicycle sharing schemes. More generally, cycling as a means of transport is encouraged in the framework of sustainable development. We therefore need to know more about cyclist road risk, according to the type of cycling: as a leisure or sporting activity or as a means of transport. These three types are fairly common now in France and they seem to have different risk patterns [2]. As a first step, we conducted here a descriptive study of cyclists' crash characteristics and cyclists' injuries, by type of cycling.

\footnotetext{
* Correspondence: emmanuelle.amoros@ifsttar.fr

${ }^{1}$ Epidemiological Research and Surveillance Unit in Transport, Occupation and Environment (UMRESTTE), Université de Lyon, 43 bvd du 11 Novembre 1918 F-69622 Lyon, France

Full list of author information is available at the end of the article
}

Police crash data are not appropriate for studying injured cyclists, because of specific strong under-reporting and selection bias on this road user type [3]. In France, the probability of injured cyclists being recorded in the police data has been estimated at 34\% for collisions with motor vehicles and at about $2 \%$ for bicycle-only crashes [4]. In this study we have used data from a road trauma registry. This is much more complete than police data, with an estimated coverage rate for injured cyclists of about $80 \%$ [5]. This study involves a total of 13,684 injured cyclists (who could be classified into a given type of cyclists, among 16,849 recorded ones). The registry contains detailed medical information on the injuries, which have been coded using the Abbreviated Injury Scale (AIS) [6].

The objective of this study is to improve our knowledge of cyclists' crashes and injuries, according to the type of cyclist. We have described the circumstances of the crash (month, day, crash opponent...), the characteristics of the cyclists (age and gender) and the nature of the cyclists' injuries (severity, types and affected body regions).

\section{Biomed Central}

다 2011 Amoros et al; licensee BioMed Central Ltd. This is an Open Access article distributed under the terms of the Creative Commons Attribution License (http://creativecommons.org/licenses/by/2.0), which permits unrestricted use, distribution, and reproduction in any medium, provided the original work is properly cited. 


\section{Methods \\ Data}

The Rhône county has a population of 1.6 million inhabitants and includes a large city (Lyon) with its suburbs and a rural area. A road trauma registry has been in operation in this county since 1996 [7]. It covers all the casualties from road crashes occurring in the Rhône county who sought medical care in health facilities and covers the whole range of injury severity: outpatients, inpatients and fatalities. All the healthcare facilities (in public and private hospitals) in the county and its surrounding area which receive crash victims contribute to the registry, i.e. about 260 health departments ranging from pre-hospital emergency care, emergency departments, intensive care units, surgery units to rehabilitation departments. The forensic medicine institutes provide data on those killed at the scene. Injury assessment is based on all the diagnoses made in the different health services the casualty passed through. Each injury is coded with the Abbreviated Injury Scale, 1990 revision [6]. Codes consist of the body region ( $R$ ), the type of anatomical structure (T), the specific anatomic structure $(\mathrm{S})$ and the level of injury $(\mathrm{N})$. An immediate severity score, known as the AIS score, is ascribed to each injury code. This has 6 levels: 1 (minor), 2 (moderate), 3 (serious), 4 (severe), 5 (critical) and 6 (beyond treatment). In this study, in order to measure the whole body injury severity of a casualty, we have used the MAIS (Maximum AIS). This is the severity score of the subject's most severe injury. An injury impairment score, between 0 and 6 , is also assigned to each injury code. This is the Injury Impairment Scale, which was proposed by Hirsh and Eppinger [8] in work for the Association for the Advancement of Automotive Medicine (AAAM). The IIS values were assigned on the basis of consensus between 35 experts. They take account of mobility, cognitive capacities, aesthetic, sensory or sexual impairment and/or pain. In order to measure the whole-body impairment of each casualty, we have used the Maximum IIS (MIIS), which is the highest IIS of his/her injuries. Over the 1996-2008 period, the Rhône road trauma registry recorded 16,849 injured cyclists, 63 of whom were killed.

The study is based on data from the Rhône road trauma registry only. This registry has been certified by the Comité National des Registres (CNR); this commission evaluates the scientific and ethical aspects of registries in France. This registry has also been approved by the Commission Nationale Informatique et Libertés (CNIL). This commission evaluates any recording of data and its use, in terms of ethics. The approval by the CNIL implies in particular the right for conducting statistical analyses (on ethically collected data).

\section{Method}

We began by calculating incidences of injured cyclists, according to age and gender, and of hospitalised cyclists, per 100,000 inhabitants, based on the population of the Rhône county.

We wished to identify different groups of cyclists according to their type of bicycle use. The first such group we identified was children (0-10 year old), who are learner cyclists. For other cyclists, i.e. teenagers and adults, we wished to distinguish between sports or leisure cycling and cycling as a means of transport. Since this information does not figure in the trauma registry, we used the location of the crash, making a distinction between 'outside towns' and 'in towns', using crash location as a proxy for cycling location. Cycling area was in turn considered as a proxy for the type of cycling: most sports or leisure cycling takes place 'outside towns', and most cycling as a means of transport takes place 'in towns'. We distinguished between the two types of location on the basis of the ZAUER classification, created by INSEE - the French National Institute of Statistics and Economic Studies - population density and population size. We defined 'in towns' as being a "rural employment cluster" (more than 5000 jobs) or an "urban cluster" that we further restricted to those with a population density of over 500 persons per $\mathrm{km}^{2}$ or a population of over 5,000. All other locations were considered to be 'outside towns'. Our division of casualties into those injured "in towns" and those injured "outside towns" also means our findings do not depend on the urbanization rate of the Rhône department, and can hence be generalised.

We have provided a descriptive analysis that compares the different types of cyclist. This analysis is based on a subsample of 13,684 cyclists, as $18.8 \%$ of the 16,849 injured cyclists could not be classified because of an unknown crash location. This subsample contained 3,671 injured children (0-10 years old), 2,032 'teenagers and adults injured outside towns', and 7,981 'teenagers and adults injured in towns'.

We have described the crash characteristics for each type of cyclist (type of road, day and month of crash, time of day (day/night), type of crash opponent if any and type of trip), as well as the characteristics of the cyclists (gender, age), and the characteristics of the injuries sustained.

We have displayed the injury patterns of all AIS 2+ injuries, ignoring minor injuries (AIS 1 ; mostly abrasions and contusions). These AIS 2+ injury patterns were described according to the type of cyclist and separately for collisions with a motor vehicle and bicycle-only crashes (no crash opponent). A distinction was made between these two types of accident as they lead to 
quite different injury patterns. The injury pattern was obtained by displaying the distribution of injuries according to both injured body region and injury type, in a matrix that closely resembles the Barell matrix [9]. The following body regions were used: head; face; neck; unspecified region of the head, face or neck; torso; vertebral column; upper extremities; lower extremities; system-wide or unspecified. The types of injury were divided into the following categories: fractures; dislocations, sprains and strains; internal organ injuries (including fractures combined with internal organ or blood vessels injuries); open wounds; contusions and abrasions (but there is none among AIS 2+injuries); unspecified; others (burns, nerve injuries, blood vessel injuries, crushing and amputations). 'Unspecified' and 'others' were not grouped together as 'unspecified head injury' is fairly informative as it means 'unconsciousness without further injury description'; the 'others' category contains injuries that are extremely rare among the cyclists. The statistical unit in these tables is the injury, not the casualty. This implies that we take into account the different injuries a casualty may have.

A detailed description, according to type of cyclist were provided for potentially fatal injuries (AIS 4, 5 or 6)

Note: In this paper, the term 'injured cyclists' includes the 63 that were killed.

\section{Results and discussion Incidence}

The mean incidence of injured cyclists over the period 1996-2008 was $80 / 100,000$. During this period the incidence fell from $99 / 100,000$ in 1996 to $70 / 100,000$ in 2008. This is not due to a decrease in cycling; on the contrary, cycling use was multiplied by 3 between 1995 and 2006 in the area of Lyon and around -which does not exactly correspond to the Rhône area but nearly[10]. On the national level, cycling use has been stable [10]. The decrease in incidence of road crashes has in fact been observed for all road user types in France (except motorized two-wheeler users) following the large-scale deployment of automatic speed control cameras in 2003 [11]. The mean incidence of hospitalized cyclists in the period was 14/100,000.

The incidence was much higher for men than for women, the mean sex-ratio being 3.6 (Figure 1). The incidence peaked in children, at 12-14 years of age for boys and 7-9 years of age for girls. These are very consistent with the pattern of exposure, in other words with the pattern of cycling according to age and gender as revealed by the French national transport survey [12]: women account for between $15 \%$ and $25 \%$ of sports cycling trips and between 30 and $44 \%$ of non-sports cycling trips. The higher incidence in males may also be

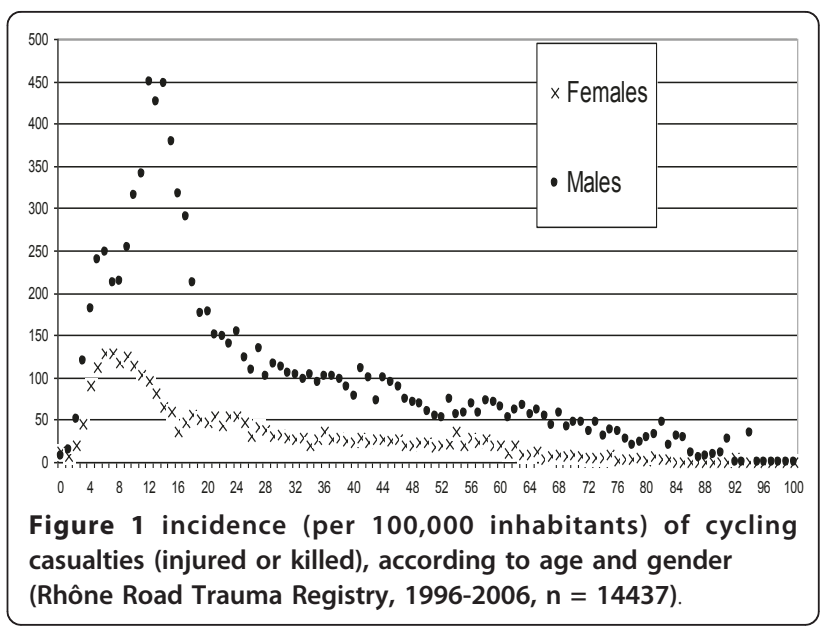

due to stronger risk-taking behaviour in comparison with females $[13,14]$. The higher incidence of bicycle injuries among men than women has also been observed in other countries [15-17].

The overall incidence was of the same order of magnitude as in Australia, where the incidence of injured cyclists who visited emergency departments was 122/ 100,000 [18]. But it was far below that observed in Sweden, where the available incidence, 398/100,000, is admittedly from the region where it is probably the highest $[19,20]$. The incidence of bicycle injuries is of course associated with the amount of bicycle use and this is much higher in Scandinavian countries than in France.

\section{Descriptive analysis of cyclist casualties, according to cyclist type Crash characteristics}

The distribution of injured cyclists according to the month of their crash (Table 1) is non-uniform with most crashes occurring between April and September, reflecting the pattern of exposure: more cycling in this period than in winter. The interesting point is a slightly greater range between winter and spring-summer for children (a range between 1.3\% and 14.8\%) and for 'teenagers and adults injured outside towns' (range between $2.5 \%$ and $12.5 \%$ ) than for 'teenagers and adults injured in towns' (range between $3.8 \%$ and $11.7 \%$ )

An interesting pattern is observed for the day of the crash. There is a non-uniform distribution with a peak on Wednesdays (when primary schools are closed) and at week-ends for injured children $(23.3 \%$ of crashes occurred on Sunday), a peak at week-ends for 'teenagers and adults injured outside towns' (27.4\% on Sunday), but a uniform distribution for 'teenagers and adults injured in towns' (15.4\% on Sunday). This is consistent with the cycling patterns [12]: sports cyclists account for 
Table 1 Crash characteristics according to cyclist type, Rhône Road Trauma Registry, 1996-2008, n = 13,684

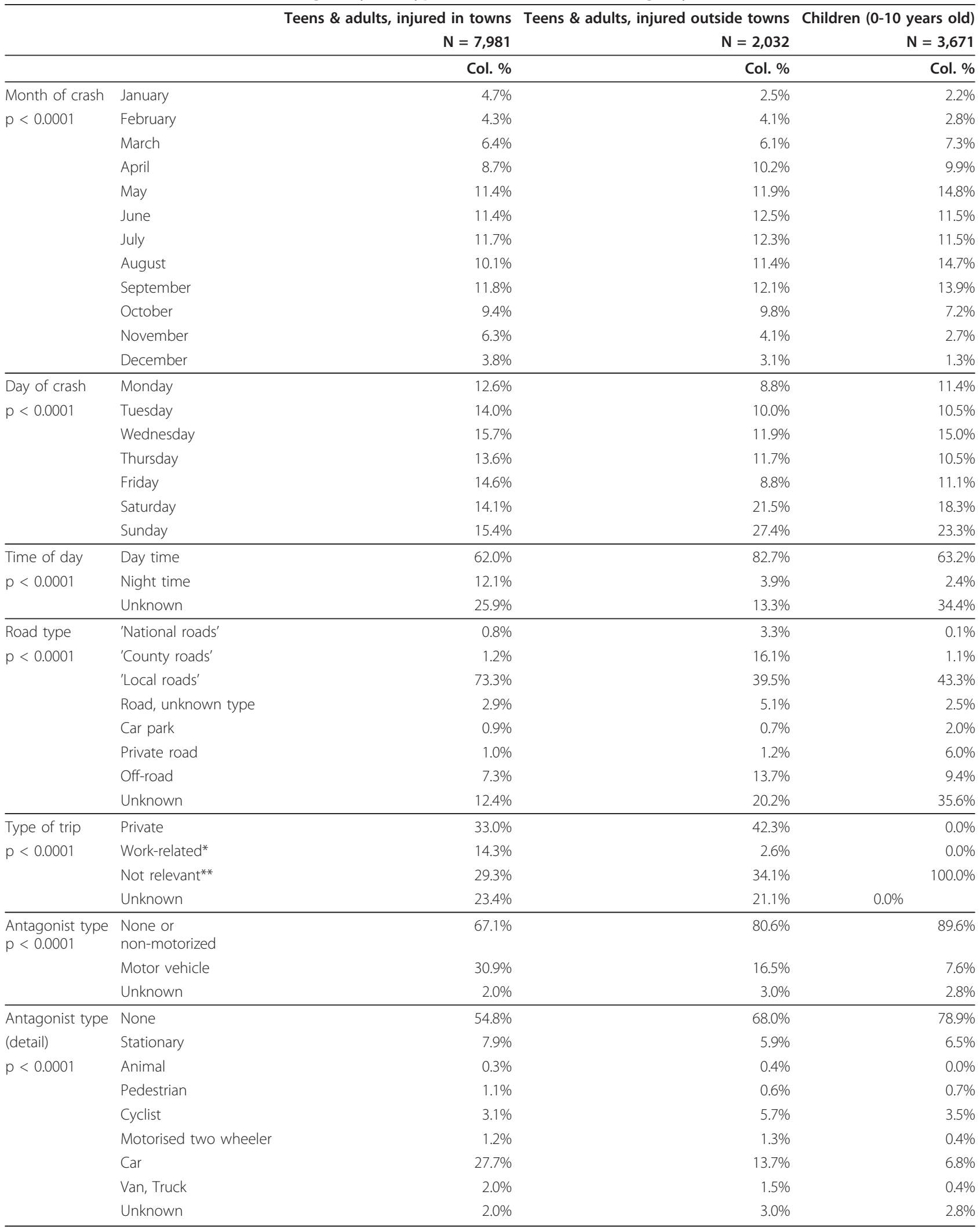

\footnotetext{
* work-related $=$ commuting or part of occupational activity
}

** not relevant $=$ outside the range 14 to 65 years old 
$34 \%$ of bicycle trips on Sundays, $22 \%$ on Saturdays and $13 \%$ on week days.

With regard to the time of day, the distribution of cyclist injuries between the day and night shows that it was quite rare for children to be injured at night and the same applies to 'teenagers and adults injured outside towns', but it was not so rare for cyclists injured in towns. This is also probably due to more cycling at night for this group, since cycling in town corresponds mostly to using the bicycle as a means of transport.

The distribution of injured cyclists according to type of road reveals a very different distribution across cyclist types. Obviously, the crashes that occurred in towns were mostly on streets $(73.3 \%)$ while a nontrivial proportion $(19.4 \%)$ of the 'teenagers and adults injured outside towns' were injured on a major road ('national' and 'county' roads).

The proportion of crashes that occurred during a work-related trip (vs a private trip) also varied with cyclist type. It was higher among 'teenagers and adults injured in towns' (14.3\%) than among those 'injured outside towns' (2.6\%) (Note: although a non-trivial proportion of trips were of unknown type, the percentages were similar for both types of cyclist, respectively $23.4 \%$ and $21.1 \%$, so that the comparison is possible).

The proportion of bicycle-only crashes varied with cyclist type, from $62.7 \%$ for 'teenagers and adults injured in towns', to $73.9 \%$ for those 'injured outside towns' and $85.4 \%$ for injured children. In slightly different terms, the proportion of crashes which involved a motor vehicle was as low as $8 \%$ among injured children, and rose to one third in 'teenagers and adults injured in towns'. Again, this is probably related to exposure to different amounts of motorised traffic. The most frequent opponent was a car (for all cyclist types).

The construction of 'cyclist type', using age and crash location as proxies, appears to be relevant: the crash circumstances of the three cyclist groups differed and they differed in ways which corresponded to the available information on cycling patterns [12].

\section{Cyclists' characteristics}

The proportion of females among the injured cyclists was highest among children (31.6\%), and lowest among 'teenagers and adults injured outside towns' (15.3\%). The 'teenagers and adults injured outside towns' were somewhat older than those injured 'in towns'.

With regard to injury severity (Table 2), 'teenagers and adults injured outside towns' were the group that was most often seriously injured (10.9\% with MAIS $3+$ ), followed by 'teenagers and adults injured in towns' $(7.2 \%$ with MAIS $3+$ ), and lastly by children ( $4.5 \%$ with MAIS $3+)$.

The pattern was similar with regard to impairment: the proportion of injured cyclists with predicted impairment one year after the crash was $25.5 \%$ for 'teenagers and adults injured outside towns', 20.9\% for those injured in towns, and $11.0 \%$ for children.

The highest hospitalization rate was for 'teenagers and adults injured outside towns' at $26 \%$ versus a rate of $18 \%$ for both children and 'teenagers and adults injured in towns'.

\section{Injury patterns}

The types of injury and injured body regions for 'teenagers and adults injured in towns' are provided in Tables 3 and 4. For those injured in bicycle-only crashes (Table 3), fractures of the upper extremities accounted for a high percentage (50\% of all their AIS $2+$ injuries); unspecified head injuries (unconsciousness without any further specified injury) accounted for $13.5 \%$, and internal organ injuries for $5.5 \%$ (3.6\% to the head and $1.7 \%$ to the torso). The injury pattern for 'teenagers and adults injured in towns' in a collision with a motor vehicle was different (Table 4): among their AIS 2+ injuries, there was a much lower percentage of fractures of the upper extremities (25.6\% vs $50 \%$ ), a higher percentage of fractures of the lower extremities, i.e. 16.7\% (vs 10.1\%), a much higher percentage of internal organ injuries, i.e. $17.0 \%$ vs $5.5 \%$ ( $8.4 \%$ to the head and $7.6 \%$ to the torso), and a slightly higher percentage of unspecified head injuries, i.e. $16.0 \%$ (vs 13.5\%).

The 'teenagers and adults injured outside towns' who were involved in bicycle-only crashes (Table 5) differed from those injured in towns in the same type of crash, with a higher share of injuries to the internal organs (9.3\% vs 5.5\%). 'Teenagers and adults injured outside towns' who were involved in collisions with a motor vehicle (Table 6) had an injury pattern that was similar to those injured in towns, but with a higher share of internal injuries to the torso $(11.2 \%$ vs $7.6 \%)$ and a higher share of vertebral fractures (11.2\% vs $5.3 \%)$.

Children injured in bicycle-only crashes (Table 7) were slightly less severely injured than 'teenagers and adults injured in towns' in crashes of this type, with a smaller proportion of injuries to the internal organs (3.1\% vs $5.5 \%)$ and a very high proportion of fractures of the upper extremities (65.4\% of all their AIS 2+ injuries). Children injured in collisions with a motor vehicle (Table 8 ) showed a different injury pattern from 'teenagers and adults injured in towns' in crashes of this type, with a slightly higher percentage of injuries to the internal organs $(22.1 \%$ vs $17.0 \%)$ especially to the head (15.3\% vs $8.4 \%)$, a slightly higher percentage of head fractures $(4.6 \%$ vs $2.7 \%)$ but a lower percentage of vertebral fractures (1.5\% vs $5.3 \%)$.

'Teenagers and adults injured outside towns' sustained more injuries on average than 'teenagers and adults injured in towns', who in turn sustained more injuries on average than children. 
Table 2 cyclists and injuries characteristics according to cyclist type, Rhône road trauma registry, 1996-2008, n = 13,684

\begin{tabular}{|c|c|c|c|c|}
\hline & & $\begin{array}{r}\begin{array}{r}\text { Teens } \& \text { adults injured in } \\
\text { towns } \\
N=7,981\end{array} \\
\end{array}$ & $\begin{array}{r}\text { Teens \& adults injured outside } \\
\text { towns } \\
\mathrm{N}=2,032\end{array}$ & $\begin{array}{r}\text { Children }(0-10 \text { years } \\
\text { old }) \\
N=3,671\end{array}$ \\
\hline & & Col. \% & Col. \% & Col. $\%$ \\
\hline Age & $0-4$ years old & $0.0 \%$ & $0.0 \%$ & $19.9 \%$ \\
\hline \multirow[t]{11}{*}{$p<0.001$} & 5-9 years old & $0.0 \%$ & $0.0 \%$ & $64.3 \%$ \\
\hline & $10-14$ years old & $20.4 \%$ & $24.7 \%$ & $15.8 \%$ \\
\hline & 15-19 years old & $16.6 \%$ & $14.0 \%$ & $0.0 \%$ \\
\hline & 20-24 years old & $12.4 \%$ & $5.7 \%$ & $0.0 \%$ \\
\hline & 25-34 years old & $17.6 \%$ & $13.0 \%$ & $0.0 \%$ \\
\hline & 35-44 years old & $12.6 \%$ & $15.9 \%$ & $0.0 \%$ \\
\hline & 45-54 years old & $9.6 \%$ & $12.4 \%$ & $0.0 \%$ \\
\hline & 55-64 years old & $5.8 \%$ & $9.0 \%$ & $0.0 \%$ \\
\hline & 65-74 years old & $3.5 \%$ & $4.1 \%$ & $0.0 \%$ \\
\hline & $75+$ years old & $1.4 \%$ & $1.0 \%$ & $0.0 \%$ \\
\hline & unknown & $0.1 \%$ & $0.2 \%$ & $0.0 \%$ \\
\hline Gender & female & $23.3 \%$ & $15.3 \%$ & $31.6 \%$ \\
\hline$p<0.001$ & male & $76.6 \%$ & $84.7 \%$ & $68.4 \%$ \\
\hline $\begin{array}{l}\text { Number of } \\
\text { injuries }\end{array}$ & 1 & $45.2 \%$ & $41.2 \%$ & $63.4 \%$ \\
\hline \multirow[t]{4}{*}{$p<0.001$} & 2 & $31.5 \%$ & $31.3 \%$ & $26.8 \%$ \\
\hline & 3 & $16.2 \%$ & $17.6 \%$ & $7.5 \%$ \\
\hline & 4 & $5.0 \%$ & $5.9 \%$ & $1.9 \%$ \\
\hline & 5 or more & $2.1 \%$ & $4.0 \%$ & $0.5 \%$ \\
\hline Injury severity & MAIS 1 (slight) & $64.7 \%$ & $54.4 \%$ & $73.6 \%$ \\
\hline \multirow[t]{5}{*}{$p<0.0001$} & MAIS 2 (moderate) & $28.1 \%$ & $34.7 \%$ & $21.9 \%$ \\
\hline & MAIS 3 (serious) & $5.6 \%$ & $8.2 \%$ & $4.2 \%$ \\
\hline & MAIS 4 (severe) & $0.9 \%$ & $1.6 \%$ & $0.3 \%$ \\
\hline & MAIS 5 (critical) & $0.2 \%$ & $0.3 \%$ & \\
\hline & MAIS 6 or killed & $0.6 \%$ & $0.7 \%$ & $0.1 \%$ \\
\hline \multirow{7}{*}{$\begin{array}{l}\text { Injury } \\
\text { impairment }\end{array}$} & MIIS 0 (none) & $79.1 \%$ & $74.5 \%$ & $89.0 \%$ \\
\hline & MIIS 1 (slight) & $19.0 \%$ & $22.5 \%$ & $10.5 \%$ \\
\hline & MIIS 2 (moderate) & $0.9 \%$ & $1.4 \%$ & $0.2 \%$ \\
\hline & MIIS 3 (serious) & $0.3 \%$ & $0.6 \%$ & $0.1 \%$ \\
\hline & MIIS 4 (severe) & $0.4 \%$ & $0.6 \%$ & $0.1 \%$ \\
\hline & MIIS 5 (critical) & $0.1 \%$ & $0.1 \%$ & $0.0 \%$ \\
\hline & MIIS 6 & $0.1 \%$ & $0.2 \%$ & $0.0 \%$ \\
\hline Medical care & Emergency Dpt. only & $81.8 \%$ & $73.8 \%$ & $82.7 \%$ \\
\hline \multirow[t]{2}{*}{$p<0.0001$} & Hospitalized & $17.8 \%$ & $25.7 \%$ & $17.3 \%$ \\
\hline & $\begin{array}{l}\text { Deceased without } \\
\text { hospitalization }\end{array}$ & $0.4 \%$ & $0.4 \%$ & $0.0 \%$ \\
\hline
\end{tabular}

It is interesting to note that 'teenagers and adults injured in towns' were on the whole less severely injured than 'teenagers and adults injured outside towns', even though the former were more often involved in a collision with a motor vehicle than the latter, and collisions with a motor vehicle are more severe than bicycle-only crashes. This can be explained by lower speeds in towns, both for the cyclists and the motor vehicles.
The potentially fatal (AIS 4+) injuries are presented in Table 9, for each type of cyclist. For this level of severity, the injury patterns for 'teenagers and adults injured in towns' and 'teenagers and adults injured outside towns' appear to be similar. About two-thirds of the severe injuries were to the head, about $20 \%$ to the thorax, and the remainder to the abdomen and the spine. The most common injuries to the head were 
Table 3 AIS $2+$ injuries of 'teenagers and adults injured in towns', in bicycle-only crashes, ( $n=2490$ injuries, mean number of injuries per cyclist $=1.25)$, Rhône Road Trauma Registry, 1996-2008

\begin{tabular}{|c|c|c|c|c|c|c|c|}
\hline & Fractures & Dislocations, Sprains and Strains & Internal organ injuries & Open wounds & Unspecified & Other & All types \\
\hline Head & $1.9 \%$ & $0.0 \%$ & $3.6 \%$ & $0.4 \%$ & $13.5 \%$ & $0.0 \%$ & $19.4 \%$ \\
\hline Face & $2.4 \%$ & $0.0 \%$ & $0.0 \%$ & $1.1 \%$ & $0.0 \%$ & $0.0 \%$ & $3.5 \%$ \\
\hline Neck & $0.0 \%$ & $0.0 \%$ & $0.0 \%$ & $0.1 \%$ & $0.0 \%$ & $0.2 \%$ & $0.3 \%$ \\
\hline Head face, neck unspec. & $0.0 \%$ & $0.0 \%$ & $0.0 \%$ & $0.0 \%$ & $0.0 \%$ & $0.0 \%$ & $0.0 \%$ \\
\hline Torso & $1.8 \%$ & $0.0 \%$ & $1.7 \%$ & $0.1 \%$ & $0.0 \%$ & $0.0 \%$ & $3.6 \%$ \\
\hline Vertebral column & $2.0 \%$ & $0.1 \%$ & $0.2 \%$ & $0.0 \%$ & $0.0 \%$ & $0.0 \%$ & $2.3 \%$ \\
\hline Upper extremities & $50.7 \%$ & $3.5 \%$ & $0.0 \%$ & $0.9 \%$ & $0.4 \%$ & $0.0 \%$ & $55.6 \%$ \\
\hline Lower extremities & $10.1 \%$ & $3.6 \%$ & $0.0 \%$ & $1.5 \%$ & $0.0 \%$ & $0.0 \%$ & $15.2 \%$ \\
\hline System-wide or unspec. & $0.0 \%$ & $0.0 \%$ & $0.0 \%$ & $0.0 \%$ & $0.0 \%$ & $0.0 \%$ & $0.0 \%$ \\
\hline All regions & $69.0 \%$ & $7.2 \%$ & $5.5 \%$ & $4.0 \%$ & $14.0 \%$ & $0.3 \%$ & $100.0 \%$ \\
\hline
\end{tabular}

Each cell shows the proportion of AIS $2+$ injuries of the corresponding category among all AIS2+ injuries of the subgroup (teens \& adults injured in towns in bicycle-only crashes); the statistical unit is the injury, not the casualty

haematomas of the cerebrum. The children seem to have mainly sustained head injuries, but this conclusion is based on a very low frequency (14 injuries).

The injury patterns observed here are fairly similar to those observed in New Zealand [21], if for head injuries we count the internal organ injuries together with the unspecified head injuries (unconsciousness, without any further injury description), and take account of the fact that we have only displayed AIS $2+$ injuries. We have excluded AIS 1 injuries, firstly because they are really minor, being predominantly contusions and abrasions, and secondly, because there are so many of them that they would obscure the more serious injuries.

\section{Strengths and weaknesses}

This study has a number of strengths. First of all, it is based on a very large number of subjects, which confers high statistical power. Second, and more importantly, these subjects were identified using a road trauma registry which covers outpatients, inpatients and fatalities. In other words, the study covers the whole range of injury severities. There might be some selection bias among the slightly injured (MAIS 1) casualties; nevertheless, the coverage rate of the registry is estimated at $80 \%$ [5]: the study sample is close to completeness and therefore to representativity.

Another way of assessing the representativity of this study is to compare it with other studies. The proportion of injured cyclists who were involved in a collision with a motor vehicle observed here was similar to that observed in other countries in studies that are based on medical data. For instance, in a Canadian study and an American study, the proportions were $31 \%$ and $30 \%$ respectively among hospitalized cyclists $[17,22]$. In an Australian study, $8 \%$ of cycling children treated in emergency departments [23] had collided with a motor vehicle.

On the contrary, the results of our study are very different from one in Germany in which two-thirds of the injured cyclists had collided with a motor vehicle [24]. However this study was based on police crash data. French police data describes a similar situation: in 2006,

Table 4 AIS $2+$ injuries of 'teenagers and adults injured in towns', in collisions with a motor vehicle ( $\mathrm{n}=1282$ injuries, mean number of injuries per cyclist $=1.64$ ), Rhône Road Trauma Registry, 1996-2008

\begin{tabular}{|c|c|c|c|c|c|c|c|}
\hline & Fractures & Dislocations, Sprains and Strains & Internal organ injuries & Open wounds & Unspecified & Other & All types \\
\hline Head & $2.7 \%$ & $0.0 \%$ & $8.4 \%$ & $0.8 \%$ & $16.0 \%$ & $0.2 \%$ & $28.0 \%$ \\
\hline Face & $3.1 \%$ & $0.1 \%$ & $0.0 \%$ & $0.6 \%$ & $0.0 \%$ & $0.1 \%$ & $3.9 \%$ \\
\hline Neck & $0.1 \%$ & $0.0 \%$ & $0.0 \%$ & $0.0 \%$ & $0.0 \%$ & $0.3 \%$ & $0.4 \%$ \\
\hline Head face, neck unspec. & $0.0 \%$ & $0.0 \%$ & $0.5 \%$ & $0.0 \%$ & $0.0 \%$ & $0.0 \%$ & $0.5 \%$ \\
\hline Torso & $3.1 \%$ & $0.0 \%$ & $7.6 \%$ & $0.2 \%$ & $0.0 \%$ & $0.4 \%$ & $11.2 \%$ \\
\hline Vertebral column & $5.3 \%$ & $0.2 \%$ & $0.4 \%$ & $0.0 \%$ & $0.1 \%$ & $0.0 \%$ & $6.0 \%$ \\
\hline Upper extremities & $25.6 \%$ & $1.6 \%$ & $0.0 \%$ & $0.8 \%$ & $0.2 \%$ & $0.1 \%$ & $28.2 \%$ \\
\hline Lower extremities & $16.7 \%$ & $3.1 \%$ & $0.1 \%$ & $1.4 \%$ & $0.0 \%$ & $0.4 \%$ & $21.7 \%$ \\
\hline System-wide or unspec. & $0.0 \%$ & $0.0 \%$ & $0.0 \%$ & $0.0 \%$ & $0.0 \%$ & $0.0 \%$ & $0.0 \%$ \\
\hline All regions & $56.6 \%$ & $5.1 \%$ & $17.0 \%$ & $3.7 \%$ & $16.2 \%$ & $1.4 \%$ & $100.0 \%$ \\
\hline
\end{tabular}

Each cell shows the proportion of AIS 2+ injuries of the corresponding category among all AIS2+ injuries of the subgroup (teens \& adults injured in towns in collisions with a motor-vehicle); the statistical unit is the injury, not the casualty 
Table 5 AIS 2+ injuries of 'teenagers and adults injured outside towns' in bicycle-only crashes ( $n=992$ injuries, mean number of injuries per cyclist $=1.34$ ), Rhône Road Trauma Registry, 1996-2008

\begin{tabular}{|c|c|c|c|c|c|c|c|}
\hline & Fractures & Dislocations, Sprains and Strains & Internal organ injuries & Open wounds & Unspecified & Other & All types \\
\hline Head & $1.6 \%$ & $0.0 \%$ & $6.0 \%$ & $0.3 \%$ & $15.3 \%$ & $0.1 \%$ & $23.4 \%$ \\
\hline Face & $4.1 \%$ & $0.0 \%$ & $0.0 \%$ & $1.1 \%$ & $0.0 \%$ & $0.0 \%$ & $5.2 \%$ \\
\hline Neck & $0.0 \%$ & $0.0 \%$ & $0.0 \%$ & $0.0 \%$ & $0.0 \%$ & $0.0 \%$ & $0.0 \%$ \\
\hline Head face, neck unspec. & $0.0 \%$ & $0.0 \%$ & $0.0 \%$ & $0.0 \%$ & $0.0 \%$ & $0.0 \%$ & $0.0 \%$ \\
\hline Torso & $2.1 \%$ & $0.0 \%$ & $3.0 \%$ & $0.1 \%$ & $0.0 \%$ & $0.0 \%$ & $5.2 \%$ \\
\hline Vertebral column & $3.1 \%$ & $0.0 \%$ & $0.2 \%$ & $0.0 \%$ & $0.0 \%$ & $0.0 \%$ & $3.3 \%$ \\
\hline Upper extremities & $43.1 \%$ & $4.7 \%$ & $0.0 \%$ & $1.0 \%$ & $0.6 \%$ & $0.1 \%$ & $49.6 \%$ \\
\hline Lower extremities & $10.5 \%$ & $1.0 \%$ & $0.0 \%$ & $1.6 \%$ & $0.0 \%$ & $0.1 \%$ & $13.2 \%$ \\
\hline System-wide or unspec. & $0.0 \%$ & $0.0 \%$ & $0.0 \%$ & $0.0 \%$ & $0.0 \%$ & $0.0 \%$ & $0.0 \%$ \\
\hline All regions & $64.6 \%$ & $5.7 \%$ & $9.3 \%$ & $4.1 \%$ & $15.9 \%$ & $0.3 \%$ & $100.0 \%$ \\
\hline
\end{tabular}

Each cell shows the proportion of AIS 2+ injuries of the corresponding category among all AIS2+ injuries of the subgroup (teens \& adults injured outside towns in bicycle-only crashes); the statistical unit is the injury, not the casualty

$88.4 \%$ of cyclist crashes in the police reports involved another vehicle [25]. This is due to the very low reporting of minor and/or of bicycle-only crashes in police data [5]. In short, our study matches other studies that are based on medical data well.

Each injury was coded with the Abbreviated Injury Scale, and there was no limit to the number of injuries per casualty. The Abbreviated Injury Scale provides a precise description of injured body regions, injury types and injury severity.

Another strength of this study is that it takes account of different cyclist types. The idea was to distinguish between cyclists according to their type of bicycle use, namely for sports or leisure purposes or as a means of transport. One weakness is that we only have an approximation of this using age and crash location (in towns vs outside towns). The approximation seems, however, to be valid since the three groups exhibit different crash patterns and these are consistent with the cycling patterns of sports and non-sport cyclists as measured by the French national travel survey [12].
Moreover, our classification of cyclists according to their crash location ("outside towns" vs "in towns"), means that our results are not affected by the urbanization rate of the Rhône county (which is rather high), and can hence be somewhat generalised.

A weakness of the study (common to many studies on cycling injuries) is the lack of exposure data, i.e. data on bicycle use. Distributions of injured cyclists according to crash circumstances (month, weekday/week-end, night/ day...) mostly reflect the pattern of cycling use. If we had data on cycling use, we could estimate the risk of crash and therefore identify the situations or groups of cyclists that are most at risk. For instance, is the probability of a crash higher in urban settings than in rural settings? one could imagine so because of more traffic and hence higher probability of conflicts; if it is higher, by how much? Does the crash risk depend on the type of road? We need such knowledge before setting bicycle safety policies.

The next step will be to obtain exposure data. This should be feasible through the existence of regional

Table 6 AIS2+ injuries of 'teenagers and adults injured outside towns' in collisions with a motor vehicle ( $n=366$ injuries, mean number of injuries per cyclist = 2.30), Rhône Road Trauma Registry, 1996-2008

\begin{tabular}{|c|c|c|c|c|c|c|c|}
\hline & Fractures & Dislocations, Sprains and Strains & Internal organ injuries & Open wounds & Unspecified & Other & All types \\
\hline Head & $2.5 \%$ & $0.0 \%$ & $9.3 \%$ & $0.8 \%$ & $10.7 \%$ & $0.0 \%$ & $23.2 \%$ \\
\hline Face & $1.9 \%$ & $0.0 \%$ & $0.0 \%$ & $0.8 \%$ & $0.0 \%$ & $0.0 \%$ & $2.7 \%$ \\
\hline Neck & $0.0 \%$ & $0.0 \%$ & $0.0 \%$ & $0.0 \%$ & $0.0 \%$ & $0.3 \%$ & $0.3 \%$ \\
\hline Head face, neck unspec. & $0.0 \%$ & $0.0 \%$ & $0.0 \%$ & $0.0 \%$ & $0.0 \%$ & $0.0 \%$ & $0.0 \%$ \\
\hline Torso & $1.9 \%$ & $0.0 \%$ & $11.2 \%$ & $0.0 \%$ & $0.0 \%$ & $0.0 \%$ & $13.1 \%$ \\
\hline Vertebral column & $11.2 \%$ & $0.0 \%$ & $0.3 \%$ & $0.0 \%$ & $0.0 \%$ & $0.0 \%$ & $11.5 \%$ \\
\hline Upper extremities & $23.8 \%$ & $1.6 \%$ & $0.0 \%$ & $1.1 \%$ & $0.0 \%$ & $0.3 \%$ & $26.8 \%$ \\
\hline Lower extremities & $18.6 \%$ & $1.4 \%$ & $0.0 \%$ & $1.6 \%$ & $0.0 \%$ & $0.5 \%$ & $22.1 \%$ \\
\hline System-wide or unspec. & $0.0 \%$ & $0.0 \%$ & $0.0 \%$ & $0.0 \%$ & $0.0 \%$ & $0.3 \%$ & $0.3 \%$ \\
\hline All regions & $59.8 \%$ & $3.0 \%$ & $20.8 \%$ & $4.4 \%$ & $10.7 \%$ & $1.4 \%$ & $100.0 \%$ \\
\hline
\end{tabular}

Each cell shows the proportion of AIS $2+$ injuries of the corresponding category among all AIS2+ injuries of the subgroup (teens \& adults injured outside towns in collisions with a motor-vehicle); the statistical unit is the injury, not the casualty 
Table 7 AIS2+ injuries of children injured in bicycle-only crashes ( $n=999$ injuries, mean number of injuries per cyclist = 1.17), Rhône Road Trauma Registry, 1996-2008

\begin{tabular}{|c|c|c|c|c|c|c|c|}
\hline & Fractures & Dislocations, Sprains and Strains & Internal organ injuries & Open wounds & Unspecified & Other & All types \\
\hline Head & $0.9 \%$ & $0.0 \%$ & $1.5 \%$ & $0.4 \%$ & $14.2 \%$ & $0.1 \%$ & $17.1 \%$ \\
\hline Face & $1.2 \%$ & $0.1 \%$ & $0.0 \%$ & $2.7 \%$ & $0.0 \%$ & $0.0 \%$ & $4.0 \%$ \\
\hline Neck & $0.0 \%$ & $0.0 \%$ & $0.0 \%$ & $0.0 \%$ & $0.0 \%$ & $0.1 \%$ & $0.1 \%$ \\
\hline Head face, neck unspec. & $0.0 \%$ & $0.0 \%$ & $0.0 \%$ & $0.0 \%$ & $0.0 \%$ & $0.0 \%$ & $0.0 \%$ \\
\hline Torso & $0.2 \%$ & $0.0 \%$ & $1.6 \%$ & $0.0 \%$ & $0.0 \%$ & $0.0 \%$ & $1.8 \%$ \\
\hline Vertebral column & $0.0 \%$ & $0.0 \%$ & $0.0 \%$ & $0.0 \%$ & $0.0 \%$ & $0.0 \%$ & $0.0 \%$ \\
\hline Upper extremities & $65.4 \%$ & $0.1 \%$ & $0.0 \%$ & $0.5 \%$ & $0.0 \%$ & $0.1 \%$ & $66.1 \%$ \\
\hline Lower extremities & $7.9 \%$ & $1.1 \%$ & $0.0 \%$ & $1.9 \%$ & $0.0 \%$ & $0.0 \%$ & $10.9 \%$ \\
\hline System-wide or unspec. & $0.0 \%$ & $0.0 \%$ & $0.0 \%$ & $0.0 \%$ & $0.0 \%$ & $0.0 \%$ & $0.0 \%$ \\
\hline All regions & $75.6 \%$ & $1.3 \%$ & $3.1 \%$ & $5.5 \%$ & $14.2 \%$ & $0.3 \%$ & $100.0 \%$ \\
\hline
\end{tabular}

Each cell shows the proportion of AIS 2+ injuries of the corresponding category among all AIS2+ injuries of the subgroup (children injured in bicycle-only crashes); the statistical unit is the injury, not the casualty

mobility surveys. The surveys on the areas of Lille and Grenoble have already been used to estimate the amount of travelled kilometres according to road user type $[26,27]$. Crash risks were further estimated, but crash data came from the police. It is planned to use the mobility survey of Lyon together with the crash data from the Rhône registry to estimate crash risks in cyclists.

The distributions of injured cyclists are nevertheless informative, in particular for exploring the differences between the cyclists' types.

\section{Conclusion}

This descriptive study yields some interesting results. First of all, cycling type appears relevant for studying bicycle crashes and injuries. Secondly, collisions with a motor-vehicle were not the most frequent crashes. The proportion of such crashes varies with cycling type: it is $8 \%$ for injured children, $17 \%$ for teenagers and adults injured outside towns and up to $31 \%$ for those injured in towns.
The severity of injuries and injury patterns are quite different between bicycle-only crashes and collisions with a motor vehicle: the latter are associated with more injuries to the lower extremities and, more importantly, injuries that are more serious, with a higher percentage of internal organ injuries. These probably match to a first blow on the legs of the cyclists (by the motor-vehicle), followed by a fall where the head is most often injured.

As a whole, children are the less severely injured, followed by 'teenagers and adults injured in towns' with the highest severity for 'teenagers and adults injured outside towns'. This applies both to collisions with a motor vehicle and bicycle-only crashes. This is probably due to lower speeds in towns, among both motor vehicles and cyclists themselves (as opposed to rural areas, where the sports cyclists reach relatively high speeds, as well as motor vehicles of course).

This indicates that lowering the speeds could be a target of bicycle safety policies. Also, bicycle safety policies should account for the different types of cyclists.

Table 8 AIS2+ injuries of children injured in collisions with a motor vehicle $(n=131$ injuries, mean number of injuries per cyclist $=1.51$ ), Rhône Road Trauma Registry, 1996-2008

\begin{tabular}{|c|c|c|c|c|c|c|c|}
\hline & Fractures & Dislocations, Sprains and Strains & Internal organ injuries & Open wounds & Unspecified & Other & All types \\
\hline Head & $4.6 \%$ & $0.0 \%$ & $15.3 \%$ & $0.0 \%$ & $24.4 \%$ & $0.0 \%$ & $44.3 \%$ \\
\hline Face & $1.5 \%$ & $0.0 \%$ & $0.0 \%$ & $0.8 \%$ & $0.0 \%$ & $0.0 \%$ & $2.3 \%$ \\
\hline Neck & $0.0 \%$ & $0.0 \%$ & $0.0 \%$ & $0.0 \%$ & $0.0 \%$ & $0.0 \%$ & $0.0 \%$ \\
\hline Head face, neck unspec. & $0.0 \%$ & $0.0 \%$ & $0.8 \%$ & $0.0 \%$ & $0.0 \%$ & $0.0 \%$ & $0.8 \%$ \\
\hline Torso & $0.8 \%$ & $0.0 \%$ & $6.1 \%$ & $0.0 \%$ & $0.0 \%$ & $0.0 \%$ & $6.9 \%$ \\
\hline Vertebral column & $1.5 \%$ & $0.0 \%$ & $0.0 \%$ & $0.0 \%$ & $0.0 \%$ & $0.0 \%$ & $1.5 \%$ \\
\hline Upper extremities & $21.4 \%$ & $0.0 \%$ & $0.0 \%$ & $0.8 \%$ & $0.0 \%$ & $0.0 \%$ & $22.1 \%$ \\
\hline Lower extremities & $19.1 \%$ & $1.5 \%$ & $0.0 \%$ & $1.5 \%$ & $0.0 \%$ & $0.0 \%$ & $22.1 \%$ \\
\hline System-wide or unspec. & $0.0 \%$ & $0.0 \%$ & $0.0 \%$ & $0.0 \%$ & $0.0 \%$ & $0.0 \%$ & $0.0 \%$ \\
\hline All regions & $48.9 \%$ & $1.5 \%$ & $22.1 \%$ & $3.1 \%$ & $24.4 \%$ & $0.0 \%$ & $100.0 \%$ \\
\hline
\end{tabular}

Each cell shows the proportion of AIS 2+ injuries of the corresponding category among all AIS2+ injuries of the subgroup (children injured collisions with a motor-vehicle); the statistical unit is the injury, not the casualty 
Table 9 Description of possibly fatal (AIS4+) injuries, by type of cyclist, Rhône road trauma registry, 1996-2008

\begin{tabular}{|c|c|c|c|c|c|c|c|c|}
\hline \multirow{2}{*}{\multicolumn{2}{|c|}{$\begin{array}{r}\begin{array}{r}\text { Teenagers } \\
\text { and adults } \\
\text { injured in } \\
\text { towns }\end{array} \\
\begin{array}{r}n=182 \\
\text { injuries }\end{array}\end{array}$}} & \multicolumn{2}{|c|}{$\begin{array}{r}\text { Teenagers } \\
\text { and adults } \\
\text { injured } \\
\text { outside } \\
\text { towns }\end{array}$} & \multicolumn{2}{|c|}{$\begin{array}{r}\text { Injured } \\
\text { children }\end{array}$} & \multicolumn{2}{|r|}{ Total } & \\
\hline & & \multicolumn{2}{|r|}{$\begin{array}{l}\mathrm{n}=77 \\
\text { injuries }\end{array}$} & \multicolumn{2}{|r|}{$\begin{array}{l}\mathrm{n}=14 \\
\text { injuries }\end{array}$} & \multicolumn{2}{|c|}{$\begin{array}{r}n=273 \\
\text { injuries }\end{array}$} & \\
\hline $\mathrm{n}$ & Col. \% & $\mathbf{n}$ & Col. \% & $\mathbf{n}$ & Col. \% & $\mathrm{n}$ & Col. \% & \\
\hline & & & & & & & & head \\
\hline 7 & $3.8 \%$ & 0 & $0.0 \%$ & 1 & $7.1 \%$ & 8 & $2.9 \%$ & whole area, major injury or massive destruction \\
\hline 1 & $0.5 \%$ & 0 & $0.0 \%$ & 0 & $0.0 \%$ & 1 & $0.4 \%$ & vertebral artery, laceration \\
\hline 3 & $1.6 \%$ & 4 & $5.2 \%$ & 0 & $0.0 \%$ & 7 & $2.6 \%$ & brain stem, contusion, hemorrhage or laceration \\
\hline 1 & $0.5 \%$ & 0 & $0.0 \%$ & 0 & $0.0 \%$ & 1 & $0.4 \%$ & cerebellum, hematoma, intracerebellar \\
\hline 3 & $1.6 \%$ & 0 & $0.0 \%$ & 0 & $0.0 \%$ & 3 & $1.1 \%$ & cerebellum, hematoma, subdural \\
\hline 0 & $0.0 \%$ & 4 & $5.2 \%$ & 0 & $0.0 \%$ & 4 & $1.5 \%$ & cerebrum, contusion(s) \\
\hline 1 & $0.5 \%$ & 0 & $0.0 \%$ & 0 & $0.0 \%$ & 1 & $0.4 \%$ & cerebrum, diffuse axonal injury \\
\hline 24 & $13.2 \%$ & 12 & $15.6 \%$ & 3 & $21.4 \%$ & 39 & $14.3 \%$ & cerebrum, hematoma, epidural or extradural \\
\hline 22 & $12.1 \%$ & 8 & $10.4 \%$ & 1 & $7.1 \%$ & 31 & $11.4 \%$ & cerebrum, hematoma, intracerebral \\
\hline 30 & $16.5 \%$ & 11 & $14.3 \%$ & 3 & $21.4 \%$ & 44 & $16.1 \%$ & cerebrum, hematoma, subdural \\
\hline 13 & $7.1 \%$ & 8 & $10.4 \%$ & 2 & $14.3 \%$ & 23 & $8.4 \%$ & cerebrum, edema \\
\hline 4 & $2.2 \%$ & 3 & $3.9 \%$ & 1 & $7.1 \%$ & 8 & $2.9 \%$ & cerebrum, intraventricular hemorrhage \\
\hline 11 & $6.0 \%$ & 3 & $3.9 \%$ & 1 & $7.1 \%$ & 15 & $5.5 \%$ & base or vault fracture \\
\hline 2 & $1.1 \%$ & 1 & $1.3 \%$ & 1 & $7.1 \%$ & 4 & $1.5 \%$ & unconscious on admission or initial observation at scene, no other injury description \\
\hline \multirow[t]{2}{*}{122} & $67.0 \%$ & 54 & $70.1 \%$ & 13 & $92.9 \%$ & 189 & $69.2 \%$ & head, total \\
\hline & & & & & & & & face \\
\hline 1 & $0.5 \%$ & 2 & $2.6 \%$ & 0 & $0.0 \%$ & 3 & $1.1 \%$ & maxilla fracture, blood loss $>20 \%$ by volume \\
\hline \multirow[t]{2}{*}{1} & $0.5 \%$ & 2 & $2.6 \%$ & 0 & $0.0 \%$ & 3 & $1.1 \%$ & face, total \\
\hline & & & & & & & & neck \\
\hline 1 & $0.5 \%$ & 0 & $0.0 \%$ & 0 & $0.0 \%$ & 1 & $0.4 \%$ & carotid, laceration, major \\
\hline \multirow[t]{2}{*}{1} & $0.5 \%$ & 0 & $0.0 \%$ & 0 & $0.0 \%$ & 1 & $0.4 \%$ & neck total \\
\hline & & & & & & & & thorax \\
\hline 2 & $1.1 \%$ & 0 & $0.0 \%$ & 0 & $0.0 \%$ & 2 & $0.7 \%$ & $\begin{array}{l}\text { (crush) bilateral obliteration of a substantial portion of the chest cavity including internal } \\
\text { organs }\end{array}$ \\
\hline 1 & $0.5 \%$ & 0 & $0.0 \%$ & 0 & $0.0 \%$ & 1 & $0.4 \%$ & aorta, thoracic, laceration, major, with hemorrhage \\
\hline 0 & $0.0 \%$ & 1 & $1.3 \%$ & 0 & $0.0 \%$ & 1 & $0.4 \%$ & heart (myocardium), contusion, severe \\
\hline 11 & $6.0 \%$ & 3 & $3.9 \%$ & 0 & $0.0 \%$ & 14 & $5.1 \%$ & lung, contusion, bilateral \\
\hline 0 & $0.0 \%$ & 2 & $2.6 \%$ & 0 & $0.0 \%$ & 2 & $0.7 \%$ & lung, laceration, bilateral with hemomediastinum \\
\hline 18 & $9.9 \%$ & 9 & $11.7 \%$ & 0 & $0.0 \%$ & 27 & $9.9 \%$ & rib cage, fracture $>3$ ribs on one side at least, with hemo-/pneumothorax \\
\hline 7 & $3.8 \%$ & 3 & $3.9 \%$ & 0 & $0.0 \%$ & 10 & $3.7 \%$ & rib cage, fracture, with flail \\
\hline \multirow[t]{2}{*}{39} & $21.4 \%$ & 18 & $23.4 \%$ & 0 & $0.0 \%$ & 57 & $20.9 \%$ & thorax, total \\
\hline & & & & & & & & abdomen \\
\hline 1 & $0.5 \%$ & 0 & $0.0 \%$ & 0 & $0.0 \%$ & 1 & $0.4 \%$ & anus, laceration, massive \\
\hline 1 & $0.5 \%$ & 1 & $1.3 \%$ & 0 & $0.0 \%$ & 2 & $0.7 \%$ & kiney, laceration, major \\
\hline 1 & $0.5 \%$ & 0 & $0.0 \%$ & 0 & $0.0 \%$ & 1 & $0.4 \%$ & liver laceration, massive, complex \\
\hline 7 & $3.8 \%$ & 0 & $0.0 \%$ & 0 & $0.0 \%$ & 7 & $2.6 \%$ & spleen laceration \\
\hline 0 & $0.0 \%$ & 0 & $0.0 \%$ & 1 & $7.1 \%$ & 1 & $0.4 \%$ & stomach laceration, massive \\
\hline \multirow[t]{2}{*}{10} & $5.5 \%$ & 1 & $1.3 \%$ & 1 & $7.1 \%$ & 12 & $4.4 \%$ & abdomen, total \\
\hline & & & & & & & & cervical spine \\
\hline 2 & $1.1 \%$ & 1 & $1.3 \%$ & 0 & $0.0 \%$ & 3 & $1.1 \%$ & brachial plexus injury \\
\hline 4 & $2.2 \%$ & 0 & $0.0 \%$ & 0 & $0.0 \%$ & 4 & $1.5 \%$ & cord contusion, laceration or complete cord syndrom \\
\hline \multirow[t]{2}{*}{6} & $3.3 \%$ & 1 & $1.3 \%$ & 0 & $0.0 \%$ & 7 & $2.6 \%$ & cervical spine, total \\
\hline & & & & & & & & thoracic spine \\
\hline 2 & $1.1 \%$ & 1 & $1.3 \%$ & 0 & $0.0 \%$ & 3 & $.1 \%$ & mplete cord syndrom, with fracture \\
\hline
\end{tabular}

$2 \quad 1.1 \% \quad 1 \quad 1.3 \% \quad 0 \quad 0.0 \% \quad 3 \quad 1.1 \%$ complete cord syndrom, with fracture 
Table 9 Description of possibly fatal (AIS4+) injuries, by type of cyclist, Rh?ô?ne road trauma registry, 1996-2008 (Continued)

\begin{tabular}{lllllllll}
\hline $\mathbf{2}$ & $\mathbf{1 . 1 \%}$ & $\mathbf{1}$ & $\mathbf{1 . 3 \%}$ & $\mathbf{0}$ & $\mathbf{0 . 0 \%}$ & $\mathbf{3}$ & $\mathbf{1 . 1 \%}$ & thoracic spine, total \\
\hline 1 & $0.5 \%$ & 0 & $0.0 \%$ & 0 & $0.0 \%$ & 1 & $0.4 \%$ & $\begin{array}{l}\text { lower extremities } \\
\text { pelvis, substantial deformation and displacement with associated vascular disruption or with } \\
\text { major retroperitoneal hematoma }\end{array}$ \\
$\mathbf{2}$ & $\mathbf{1 . 1 \%}$ & $\mathbf{0}$ & $\mathbf{0 . 0 \%}$ & $\mathbf{0}$ & $\mathbf{0 . 0 \%}$ & $\mathbf{2}$ & $\mathbf{0 . 7 \%}$ & lower extremities, total \\
\hline
\end{tabular}

However, additional recommendations about bicycle safety policies can not be given before exposure data can be obtained and used in the estimation of crash risks.

\section{List of abbreviations used}

AIS: Abbreviated Injury Scale; MAIS: Maximum AIS = AIS severity score of the most severe injury; ZAUER: Zones d'Aire Urbaine et de l'Espace Rural = Zoning of Urban Areas and Rural Space

\section{Acknowledgements}

We would like to thank all the persons who took part in data collection and data recording, both within the Rhône Road Trauma Registry Association (ARVAC, president E Javouhey), and within the IFSTTAR-UMRESTTE research unit (B Laumon, scientific adviser and A Ndiaye, medical coordinator). We thank Kevin Riley for reading the manuscript and correcting our English. Finally we would like to thank the two reviewers, Thomas Goetschi and Stephen Bowman for their constructive comments.

Funding

Our thanks are due to the French Institute for Public Health Surveillance (InVS) for funding the study (Contract number: convention InVS J06-24).

\section{Author details}

${ }^{1}$ Epidemiological Research and Surveillance Unit in Transport, Occupation and Environment (UMRESTTE), Université de Lyon, 43 bvd du 11 Novembre 1918 F-69622 Lyon, France. ${ }^{2}$ Epidemiological Research and Surveillance Unit in Transport, Occupation and Environment (UMRESTTE), French Institute of Science and Technology for Transport, Development and Networks (IFSTTAR), 25 avenue François Mitterrand, BRON, F-69675, France. ${ }^{3}$ Epidemiological Research and Surveillance Unit in Transport, Occupation and Environment (UMRESTTE), Université Lyon 1, Lyon, F-69373, France. ${ }^{4}$ Injury Unit, Department of Chronic Diseases and Trauma, French Institute for Public Health Surveillance (InVS), 12 rue du Val d'Osne, Saint-Maurice, F94415, France.

\section{Authors' contributions}

EA participated in the design of the study, conducted the statistical analysis, and drafted the manuscript. MC participated in the design of the study, in the interpretation of results and helped to draft the manuscript. BT and BL initiated the study, participated in the design and in the supervision. All the authors read and approved the final manuscript.

\section{Competing interests}

The authors declare that they have no competing interests.

Received: 10 February 2011 Accepted: 17 August 2011

Published: 17 August 2011

\section{References}

1. Papon F, De Solère R: Les modes actifs: marche et vélo de retour en ville. La revue, Commissariat général au développement durable - Service de l'observation et des statistiques 2010.

2. Adage, CFES, CNAMTS: Etude exploratoire sur la sécurité en vélo et le port du casque. 2002

3. Elvik $R$, Mysen $A B$ : Incomplete accident reporting; meta-analysis of studies made in 13 countries. Transportation Research Record 1999, 1665:133-140.
4. Amoros E, Martin JL, Laumon B: Under-reporting of road crash casualties in France. Accident Analysis and Prevention 2006, 38(4):627-635.

5. Amoros E: Les blessés par accidents de la route: estimation de leur nombre et de leur gravité lésionnelle, France, 1996-2004; modélisation à partir d'un registre médical (Rhône) et des données policières (France). PhD thesis Université Lyon 1; 2007.

6. AAAM: Association for the Advancement of Automotive Medicine, The Abbreviated Injury Scale (1990 revision). Des Plaines, Illinois; 1990.

7. Laumon B, Martin JL, Collet P, Chiron M, Verney MP, Ndiaye A, Vergnes I: A French road accident trauma registry: first results. 41st annual conference of the Association for the Advancement of Automotive Medecine: November 10-11 1997; Orlando, Florida 1997, 127-137.

8. Hirsh AE, Eppinger R: Impairment scaling from the Abbreviated Injury Scale. Association for the Advancement of Automotive Medicine: 8-10 october 1984 1984; Denver, Colorado 1984, 209-218.

9. Barell V, Aharonson-Daniel L, Fingerhut LA, Mackenzie EJ, Ziv A, Boyko V, Abargel A, Avitzour M, Heruti R: An introduction to the Barell body region by nature of injury diagnosis matrix. Injury Prevention 2002, 8(2):91-96.

10. CERTU: La mobilité urbaine des années 2000. Mobilités: faits et chiffres 2007, fiche $n^{\circ} 3$.

11. ONISR: La sécurité routière en France, bilan de l'année 2004. Paris: La documentation Française; 2005.

12. Papon F: La marche et la bicyclette dans les enquêtes Transport auprès des ménages, volume 1, Typologie des cyclistes. rapport de convention 1999, 101.

13. Granié M-A: Différences de sexe et internalisation des règles sur la propension des enfants à prendre des risques à vélo. Recherches Transport Sécurité 2011, 27:34-41.

14. Martin JL, Lafont S, Chiron M, Gadegbeku B, Laumon B: Differences between males and females in traffic accident risk in France. Revue d'Epidémiologie et de Santé Publique 2004, 52(4) [http://www.e2med.com/ resp.].

15. Ekman R, Welander G, Svanström L, Schelp L, Santesson P: Bicycle-related injuries among the elderly-a new epidemic? Public Health 2001, 115(1):38-43.

16. Haileyesus T, Annest $\lrcorner$, Dellinger AM: Cyclists injured while sharing the road with motor vehicles. Inj Prev 2007, 13(3):202-206.

17. Konkin DE, Garraway N, Hameed SM, Brown DR, Granger R, Wheeler S, Simons RK: Population-based analysis of severe injuries from nonmotorized wheeled vehicles. American Journal of Surgery 2006, 191(5):615-618.

18. Sikic M, Mikocka-Walus AA, Gabbe BJ, McDermott FT, Cameron PA: Bicycling injuries and mortality in Victoria, 2001-2006. the Medical Journal of Australia 2009, 190(7):353-356.

19. Eilert-Petersson E, Schelp L: An epidemiological study of bicycle-related injuries. Accident Analysis \& Prevention 1997, 29(3):363-372.

20. Schelp L, Ekman R: Road traffic accidents in a Swedish community. Public Health 1990, 104:55-64

21. Tin Tin S, Woodward A, Ameratunga S: Injuries to pedal cyclists on New Zealand roads, 1988-2007. BMC Public Health 2010, 10:655.

22. Shah S, Sinclair SA, Smith GA, Xiang H: Pediatric hospitalizations for bicycle-related injuries. Inj Prev 2007, 13(5):316-321.

23. Acton CH, Thomas S, Nixon JW, Clark R, Pitt WR, Battistutta D: Children and bicycles: what is really happening? Studies of fatal and non-fatal bicycle injury. Inj Prev 1995, 1(2):86-91.

24. Richter M, Otte D, Haasper C, K K, Probst C, Westhoff J, Sommer K, Krettek C: The Current Injury Situation of Bicyclists-A Medical and Technical Crash Analysis. The Journal of Trauma: Injury, Infection, and Critical Care 2007, 62:1118-1122.

25. ONISR: Bicyclettes. Grands thèmes de l'insécurité routière 2008. 
26. Gabet p: Méthode de calcul d'une exposition au risque d'accident en milieu urbain; application de la méthode sur la communauté urbaine de Lille.Edited by: Rapports L. CERTU-CETE Nord Picardie; 2005.

27. Mercat N: Méthode de calcul d'une exposition au risque d'accident en milieu urbain; application de la méthode sur la région urbaine de Grenoble.Edited by: Rapports L. CERTU-Altermodal; 2006.

Pre-publication history

The pre-publication history for this paper can be accessed here: http://www.biomedcentral.com/1471-2458/11/653/prepub

doi:10.1186/1471-2458-11-653

Cite this article as: Amoros et al: The injury epidemiology of cyclists based on a road trauma registry. BMC Public Health 2011 11:653.

Submit your next manuscript to BioMed Central and take full advantage of:

- Convenient online submission

- Thorough peer review

- No space constraints or color figure charges

- Immediate publication on acceptance

- Inclusion in PubMed, CAS, Scopus and Google Scholar

- Research which is freely available for redistribution

Submit your manuscript at www.biomedcentral.com/submit 